\title{
MODULATION OF CAPSAICIN-INDUCED NEUROGENIC VASODILATION BY ACUTE PSYCHOLOGICAL STRESS
}

\author{
CRISTIAN SCHEAU ${ }^{1}$, MIHAELA ADRIANA ILIE ${ }^{2,6 *}$, OVIDIU GRIGORE ${ }^{3}$, ALEXANDRA $^{2}$ \\ IOANA MIHĂILESCU ${ }^{4}$, ANA CĂRUNTU ${ }^{5}$, LIVIA GRAȚIELA MIHAI ${ }^{1}$, IOANA ANCA \\ BĂDĂRĂU ${ }^{1}$, DANIEL BODA ${ }^{6,7}$, CONSTANTIN CĂRUNTU ${ }^{1,6,7}$ \\ ${ }^{1}$ Department of Physiology, "Carol Davila" University of Medicine and Pharmacy, 050474, Bucharest, Romania \\ ${ }^{2}$ Department of Biochemistry, "Carol Davila” University of Medicine and Pharmacy, 050474, Bucharest, Romania \\ ${ }^{3}$ Department of Applied Electronics and Information Engineering, Polytechnic University of Bucharest, 061071, Bucharest, \\ Romania \\ ${ }^{4}$ Department of Medical Psychology, "Carol Davila” University of Medicine and Pharmacy, 050474, Bucharest, Romania \\ 5 "Carol Davila" Central Military Emergency Hospital, 010825, Bucharest, Romania \\ ${ }^{6}$ Dermatology Research Laboratory, "Carol Davila” University of Medicine and Pharmacy, 050474, Bucharest, Romania \\ ${ }^{7}$ Department of Dermatology, "Prof. N.C. Paulescu” National Institute of Diabetes, Nutrition and Metabolic Diseases, \\ 011233, Bucharest, Romania
}

*corresponding author: mihaelaadriana2005@yahoo.com

Manuscript received: November 2020

\begin{abstract}
We have investigated the effect of psychological stress on capsaicin-induced cutaneous vasodilation. A total of 40 healthy volunteers were randomly included in two groups, a stress-induced group and a control group. Capsaicin was applied topically in both groups and in vivo reflectance confocal microscopy images of the dermo-epidermal junction were subsequently acquired from the same area at $0,10,25$ and 40 minutes post-application. The capillary surface area, perimeter, and maximum diameter were evaluated comparatively between the two groups. Statistically significant higher values were obtained in the stress group at 25 and 40 minutes after exposure to capsaicin. These findings demonstrate that psychological stress can amplify the localized skin microvascular response within neurogenic inflammation induced by topical capsaicin.
\end{abstract}

\section{Rezumat}

A fost investigat efectul stresului psihologic asupra răspunsului vasodilatator cutanat indus de capsaicină. Un număr de 40 voluntari sănătoși au fost incluși în mod randomizat în două grupuri, un grup în care s-a indus stresul și un grup control. A fost aplicată topic capsaicina în ambele grupuri, apoi au fost achiziționate imagini de microscopie confocală de reflectanță in vivo din aceeași zonă cutanată, de la nivelul joncțiunii dermo-epidermice, la $0,10,25$ și 40 de minute după aplicare. Au fost evaluate comparativ aria, perimetrul și diametrul maxim al capilarelor în ambele grupuri. Au fost obținute valori semnificativ mai mari în grupul stres la 25 și 40 de minute după aplicarea capsaicinei. Aceste date arată că stresul psihologic poate amplifica răspunsul microvascular cutanat localizat din cadrul inflamației neurogenice induse de capsaicina aplicată topic.

Keywords: capsaicin, neurogenic inflammation, stress, in vivo reflectance confocal microscopy

\section{Introduction}

Cutaneous neurogenic inflammation highlights the complex interactions existing between the skin and the nervous system [10] as various dermatological diseases can be triggered by neurogenic inflammation and subsequently aggravated in the context of acute or chronic psychological stress [34]. The mechanisms that underlie stress-induced exacerbation of skin inflammation are intensively studied and include effects upon nociceptive nerve fibres, neuroendocrine and immune factors, as well as vasoactive amines release from mast cells [6, 22].

Capsaicin-induced cutaneous inflammation is one of the best-known research models of neurogenic inflammation that has been studied on humans [6, 11]. Capsaicin is a natural vanilloid, responsible for the pungency of chili peppers, and a highly selective agonist for the transient receptor potential cation channel, subfamily V, member 1 (TRPV1) [37]. TRPV1 is also activated by various physical and chemical stimuli as well as substances such as endocannabinoids or other endogenous ligands [8, 36]. In the skin, TRPV1 activation increases substance $\mathrm{P}$ (SP) and calcitonin gene-related peptide (CGRP) release from sensory nerve endings depicted by a localized transient inflammatory response and sustained increased blood flow that has been observed for up to one hour after topical administration of capsaicin [35]. Moreover, capsaicin has been investigated for its impact in tumorigenesis, especially cutaneous, and most studies cite a dose- 
FARMACIA, 2021, Vol. 69, 4

related chemopreventive role, which is mostly TRPV1mediated [7, 23, 24].

In vivo reflectance confocal microscopy ( $\mathrm{RCM})$ is a novel imaging technique that visualizes the cutaneous tissue to a depth that corresponds to the superficial dermis in a non-invasive manner, with high resolution and repeatability [18]. Although currently used mostly in the diagnosis and investigation of skin cancers, in vivo RCM also has applications in skin inflammatory disorders and the evaluation of physiopathological responses of the skin to various stimuli [2, 9, 14, 33].

This paper aims to investigate the effects of acute psychological stress upon skin neurogenic inflammation induced by topical capsaicin by evaluating the cutaneous micro-vascularization response through in vivo RCM. The current study continues previous works of our research laboratory which have demonstrated that capsaicin-induced cutaneous neurogenic inflammation and blood flow changes can be evaluated through in vivo $\mathrm{RCM}$, and that acute stress can increase the area of inflammation induced by capsaicin when investigated by skin thermography [10].

\section{Materials and Methods}

\section{Participants}

Forty healthy volunteers (18 males, 22 females), aged 18 to 35 years (average $23.68 \pm 5.03$ ) were included in the study. All subjects were undergoing or have graduated university studies and none was suffering from any cardiovascular, respiratory, psychiatric, neoplastic or autoimmune disorders or was under any medication. Among the exclusion criteria were allergy to capsaicin, traumatic events in the last 24 hours or infectious diseases in the last 30 days. Participants were advised not to smoke, consume alcohol, coffee, tea or other caffeine-rich beverages, and to avoid strenuous physical activity the day before and in the morning of the examination.

The participants were randomly divided into two groups: a stress group ( 9 males, 12 females, average age $24.1 \pm 5.15$ years old) and a control group ( 9 males, 10 females, average age $23.21 \pm 4.86$ years old).

An informed consent was obtained from all enrolled participants. The study was performed according to national research regulations and the tenets of the Helsinki Declaration, and the local ethics committee approval was obtained.

Baseline stress evaluation

The participants' level of stress was evaluated using the Perceived Stress Scale (PSS), which is a psychometric test conceived to be appropriate for college-level responders and yields 14 questions that quantify the overall perception of the stress accumulated in the last month.

Stress inducing procedure
The protocol for inducing stress is complex and has been thoroughly detailed in our previous paper [10]. Briefly, stress is induced in three consecutive phases: viewing disturbing imagery, a mental arithmetic computerized test with negative feedback control, and the application of the Raven Standard Progressive Matrices test.

Capsaicin

The $1 \%$ capsaicin solution was obtained by diluting capsaicin (M-2028; Sigma Chemical Co, St Lois, MO, USA) in the immersion oil (Crodamol oil; Croda Inc., Edison, NJ, USA) used for in vivo RCM. A volume of $7.5 \mu \mathrm{L}$ of capsaicin solution was applied on the dorsal region of the non-dominant hand in all subjects with an automated pipette (Biohit Proline Single-Channel Pipettor, Variable Volume, 0.5 - 10 $\mu \mathrm{L})$. The area of interest was isolated using a plastic patch attached to a metallic ring that was used as a support for the in vivo RCM objective. As the scanning procedure requires direct contact with the skin, the pressure on the skin surface was carefully monitored to prevent capillary compression.

In vivo reflectance confocal microscopy

The Vivascope 1500 (Lucid Inc., Rochester, NY, USA) RCM featuring a 30x lens and a gallium arsenide laser source was used in our study. The field of view was $500 \times 500 \mu \mathrm{m}$ and the resolution was $0.4 \mu \mathrm{m}$ in the lateral plane and $1.9 \mu \mathrm{m}$ in the vertical plane. Images were saved in the bitmap image file format.

Experimental protocol

The study was performed under medical supervision at the Dermatology Research Laboratory of "Carol Davila" University of Medicine and Pharmacy, Bucharest, Romania within the Department of Dermatology, "Prof. N.C. Paulescu" National Institute of Diabetes, Nutrition and Metabolic Diseases Bucharest, Romania. Standard room temperature and humidity were ensured throughout the experiment. The subjects filled the informed consent and the PSS and then underwent either the stress-inducing procedure (stress group) or a slideshow of neutral images (control group). RCM was performed in all subjects, evaluating the cutaneous micro-vascularization at $0,10,25$ and 40 minutes from the application of the topical capsaicin solution. Sequential images of $4 \times 4 \mathrm{~mm}$ were obtained from the dermo-epidermal junction level. At this depth, in optical horizontal sections, the basal layer forms bright rings, surrounded by the honeycomb-patterned spinous layer. The dark areas inside the rings correspond to the dermal papillae and contain the virtually sectioned capillary loops that appear as black holes. Blood cells can be observed in real-time in video recordings as bright structures inside dermal capillaries (Figure 1). The images were analysed by two investigators in a blinded manner using Image J 1.45 software; the capillaries of at least 15 dermal papillae were analysed in each subject; the studied parameters were the area, 
perimeter and maximum diameter (Feret) of the capillaries in the dermal papillae.

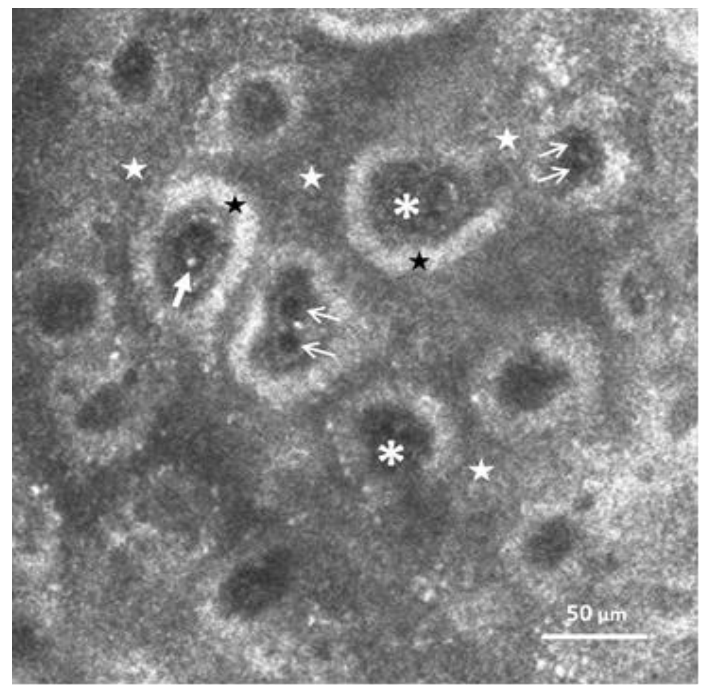

Figure 1.

In vivo reflectance confocal microscopy image taken at the level of the dermo-epidermal junction. At this depth, dermal capillaries can be seen as black round holes (thin arrow) surrounded concentrically by dark areas (asterisk), bright rings (black star) and honeycomb-patterned spinous layer (white star).

The dark areas are the dermal papillae and the bright rings correspond to the melanin-rich basal layer.

Blood cells can be observed in the lumina of capillaries as bright elements (thick arrow).

\section{Statistical analysis}

Statistical interpretation was performed using MedCalc ${ }^{\circledR}$ Statistical Software version 14 (MedCalc Software bvba, Ostend, Belgium; www.medcalc.org; 2014). Sample data were tested for normality using the Shapiro-Wilk test. The comparative analysis between groups was performed using t-test in case of normal distribution of data, while the Mann-Whitney test was used in cases when data was not normally distributed. The changes of investigated parameters within the two study groups were evaluated using repeated measures analysis of variance employing the Greenhouse-Geisser and Huynh-Feldt estimates of sphericity for corrections, followed by a pairwise comparison employing the Bonferroni correction for multiple comparisons. Results are presented as average \pm standard deviation. The correlations were considered statistically significant when $\mathrm{p}<0.05$.

\section{Results and Discussion}

No statistically significant differences were noted for participants' age ( $p=0.6240$, Mann-Whitney test for independent samples, two-tailed probability), gender ( $p=0.9746$, Chi-squared test) or baseline stress level evaluated by PSS $(p=0.7301$, independent samples t-test assuming equal variances, two-tailed probability) between the stress and control groups.

Baseline values of the morphological parameters were evaluated for all participants in the study. No statistically significant differences were recorded when comparing the mean values of the capillary area $(\mathrm{p}=$ 0.1194, Mann-Whitney test for independent samples, two-tailed probability), perimeter $(\mathrm{p}=0.1560$, independent samples t-test assuming equal variances, two-tailed probability) and maximum diameter ( $\mathrm{p}=$ 0.1425 , independent samples t-test assuming equal variances, two-tailed probability) between the stress and control groups. The capsaicin-induced capillary response was evaluated through measurements of the area, perimeter and maximum diameter of the capillaries at 10,25 and 40 minutes in both groups and the results were expressed as percentage of the baseline values (measured at 0 minutes). The variation in time of each parameter within the study groups was analysed, and a statistically significant increase was noted for all parameters in both groups (Table I). Every parameter in both groups showed a significant increase at 25 and 40 minutes compared to the values recorded at 10 minutes (Figure 2), the early increase (from 10 to 25 minutes) being more significant in the stress group. Comparison of the parameters between groups revealed significantly higher values in the stress group when compared to the control, at 25 and 40 minutes for all parameters, and at 10 minutes for the maximum diameter, respectively (independent samples t-test assuming equal variances, two-tailed probability); the findings are presented in Table II. Comparisons between groups for each parameter are represented in Figure 3.

In this study, we demonstrate the amplifying effect of acute psychological stress on dermal microvascularization in the setting of localized neurogenic inflammation induced by topical capsaicin using in vivo RCM. The capsaicin-induced vasodilatory response is mediated through activation of TRPV1 receptor located in the skin in type $\mathrm{C}$ and A-delta nociceptive nerve endings, followed by the release of neuropeptides and further triggering vasodilation directly and also indirectly, through mast-cell degranulation $[5,12,13,25]$. Therefore, skin neurovascular reactivity to topical capsaicin represents an ideal research model to study the interactions between the skin and the nervous system [21, 29].

Non-invasive in vivo measurements are preferred procedures in any human study, and technological developments in the last decades allowed for methods such as optical coherence tomography, multiparametric and perfusion imaging studies and RCM to demonstrate metabolic and histologic changes without significant risks to the participants $[17,26,35]$. Capsaicininduced cutaneous inflammatory response has been evaluated until now using laser Doppler imaging [27, 31], thermography [10], planimetry [4] and in vivo 
FARMACIA, 2021, Vol. 69, 4

RCM [28]. Of these non-invasive techniques, in vivo RCM is the most useful for repeatedly investigating the morphology of dermal micro- vascularization, with a high, quasi-microscopic resolution and the dynamics of skin blood flow, in real-time [3].

Table I

Detailed analysis of the statistical difference between the measurements taken for each parameter at different intervals within each group

\begin{tabular}{|c|c|c|c|c|c|}
\hline \multirow{2}{*}{ Group } & \multirow{2}{*}{ Parameter } & \multicolumn{3}{|c|}{$\begin{array}{l}\text { Significance of difference between } \\
\text { measurements at different intervals }\end{array}$} & \multirow{2}{*}{$\begin{array}{l}\text { Overall significance } \\
\text { level of the difference } \\
\text { within each group }\end{array}$} \\
\hline & & $\begin{array}{l}\mathbf{1 0} \rightarrow \mathbf{2 5} \\
\text { minutes }\end{array}$ & $\begin{array}{l}25 \rightarrow 40 \\
\text { minutes }\end{array}$ & $\begin{array}{l}10 \rightarrow 40 \\
\text { minutes }\end{array}$ & \\
\hline \multirow{3}{*}{ Control } & Area & $p=0.0116$ & $\mathrm{p}=0.2383$ & $\mathrm{p}<0.0001$ & $\mathrm{p}<0.0001$ \\
\hline & Perimeter & $\mathrm{p}=0.0061$ & $\mathrm{p}=0.3705$ & $\mathrm{p}<0.0001$ & $\mathrm{p}<0.0001$ \\
\hline & Maximum diameter & $\mathrm{p}=0.0035$ & $p=0.1652$ & $\mathrm{p}<0.0001$ & $\mathrm{p}<0.0001$ \\
\hline \multirow{3}{*}{ Stress } & Area & $\mathrm{p}=0.0010$ & $p=0.1757$ & $\mathrm{p}=0.0058$ & $p=0.0019$ \\
\hline & Perimeter & $\mathrm{p}=0.0005$ & $\mathrm{p}=0.1690$ & $\mathrm{p}=0.0014$ & $\mathrm{p}=0.0005$ \\
\hline & Maximum diameter & $p=0.0004$ & $p=0.3144$ & $p=0.0021$ & $p=0.0007$ \\
\hline
\end{tabular}

Table II

Average values for the three parameters in the two study groups and the statistical analysis of the differences

\begin{tabular}{ccccc}
\hline \multirow{2}{*}{ Group } & \multirow{2}{*}{ Parameter } & \multicolumn{2}{c}{ RCM measurement variation (\%) } \\
\cline { 3 - 5 } & & 10 minutes & 25 minutes & 40 minutes \\
\hline \multirow{2}{*}{ Control } & Area & $112.04 \pm 17.09$ & $124.79 \pm 21.78$ & $131.34 \pm 19.93$ \\
& Perimeter & $105.32 \pm 7.82$ & $111.49 \pm 9.59$ & $114.0 \pm 8.88$ \\
& Maximum diameter & $104.56 \pm 7.24$ & $110.23 \pm 8.59$ & $113.03 \pm 7.90$ \\
\hline \multirow{2}{*}{ Stress } & Area & $121.20 \pm 17.33$ & $147.35 \pm 28.18$ & $161.71 \pm 50.78$ \\
& Perimeter & $110.27 \pm 7.82$ & $121.42 \pm 10.99$ & $126.44 \pm 17.81$ \\
& Maximum diameter & $109.78 \pm 7.40$ & $120.28 \pm 9.98$ & $124.20 \pm 16.33$ \\
\hline Significance of & Area & $\mathrm{p}=0.0598 \dagger$ & $\mathrm{p}=0.0085$ & $\mathrm{p}=0.0060 \dagger$ \\
difference between & Perimeter & $\mathrm{p}=0.0589$ & $\mathrm{p}=0.0051$ & $\mathrm{p}=0.0039 \dagger$ \\
groups & Maximum diameter & $\mathrm{p}=0.0343$ & $\mathrm{p}=0.0019$ & $\mathrm{p}=0.0043 \dagger$ \\
\hline
\end{tabular}

$\dagger$ Mann-Whitney test (independent samples), two-tailed probability.

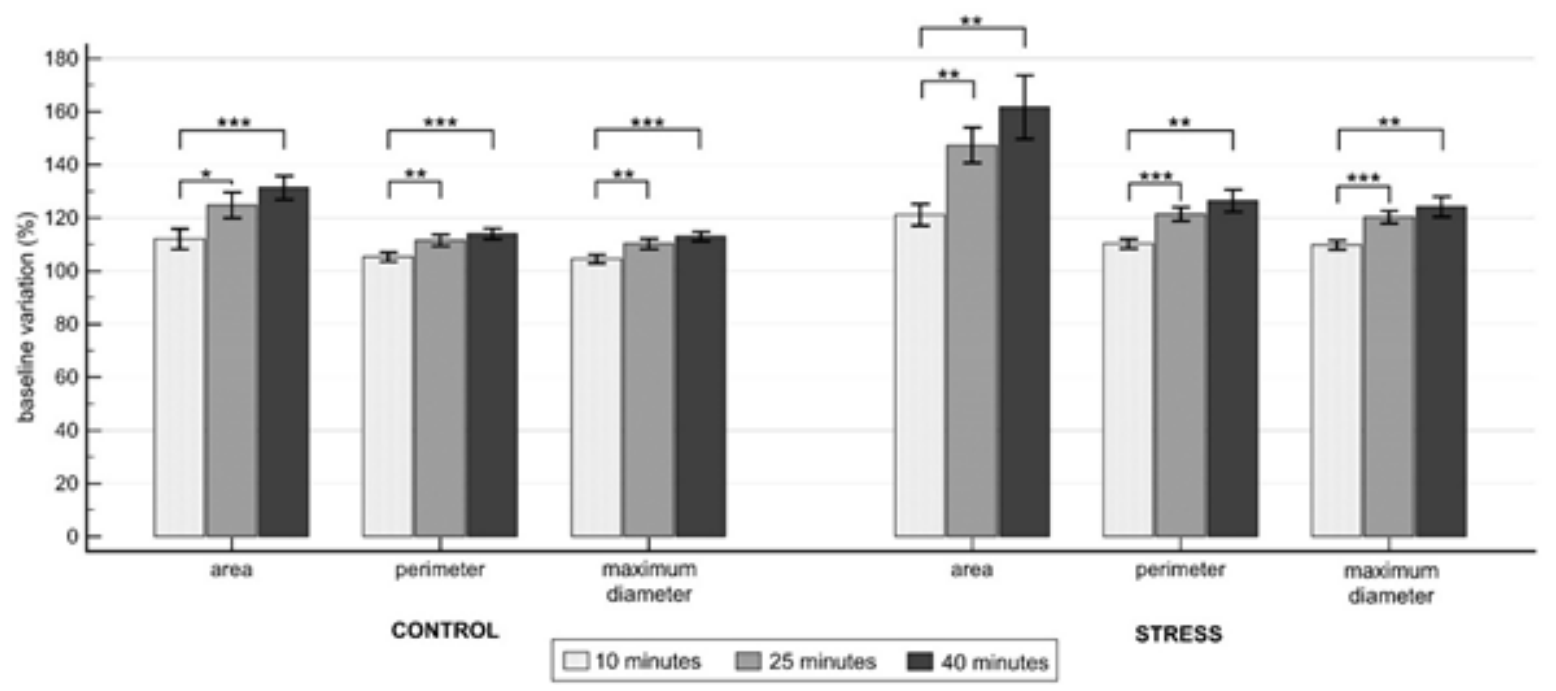

Figure 2.

Parameter variation at 10,25 and 40 minutes in the two studied groups

$$
(* * * \mathrm{p}<0.001, * * \mathrm{p}<0.01, * \mathrm{p}<0.05)
$$



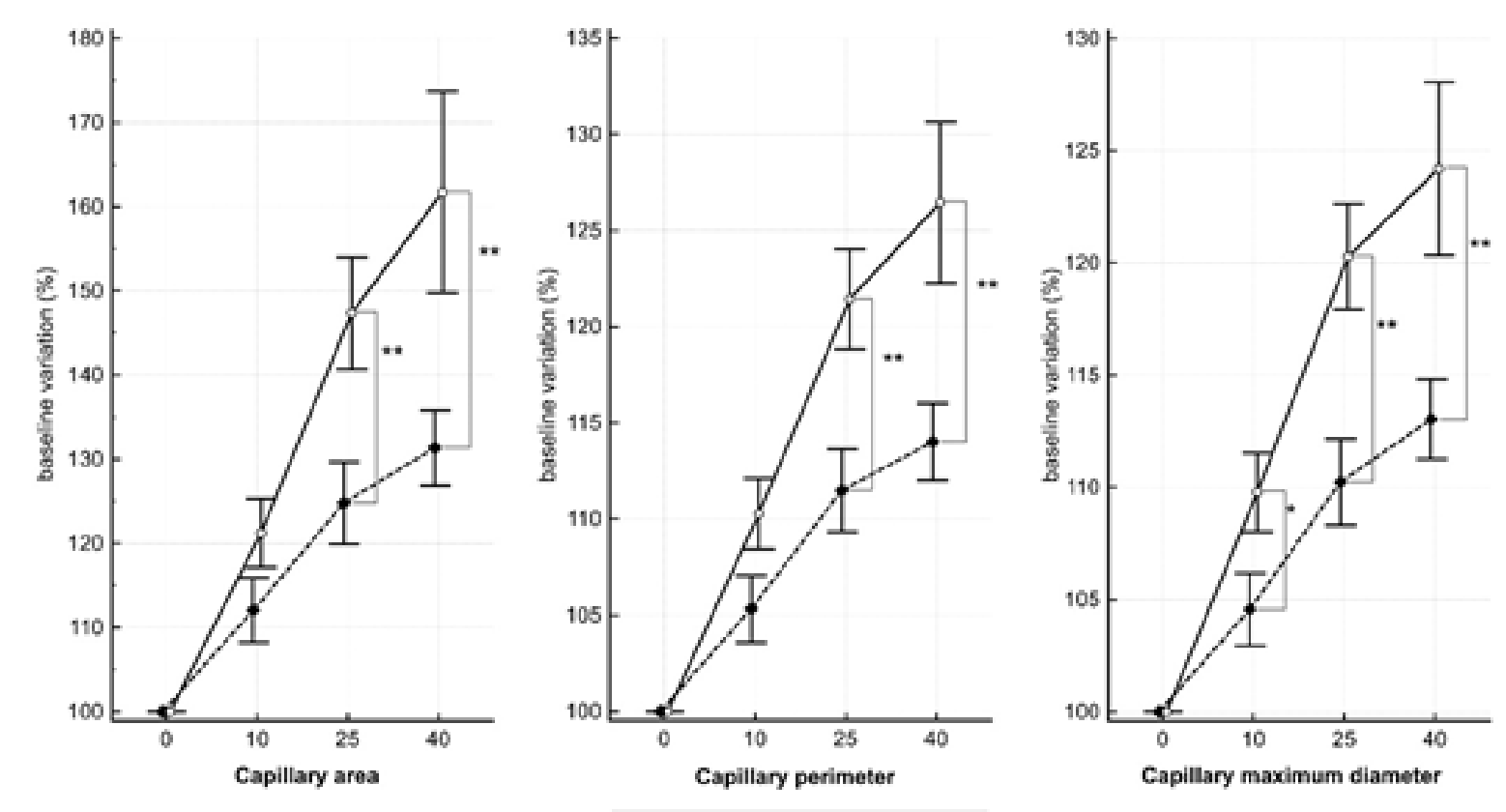

Figure 3.

Comparison of each parameter variation between groups, at 10, 25 and 40 minutes, respectively $(* * * \mathrm{p}<0.001, * * \mathrm{p}<0.01, * \mathrm{p}<0.05)$
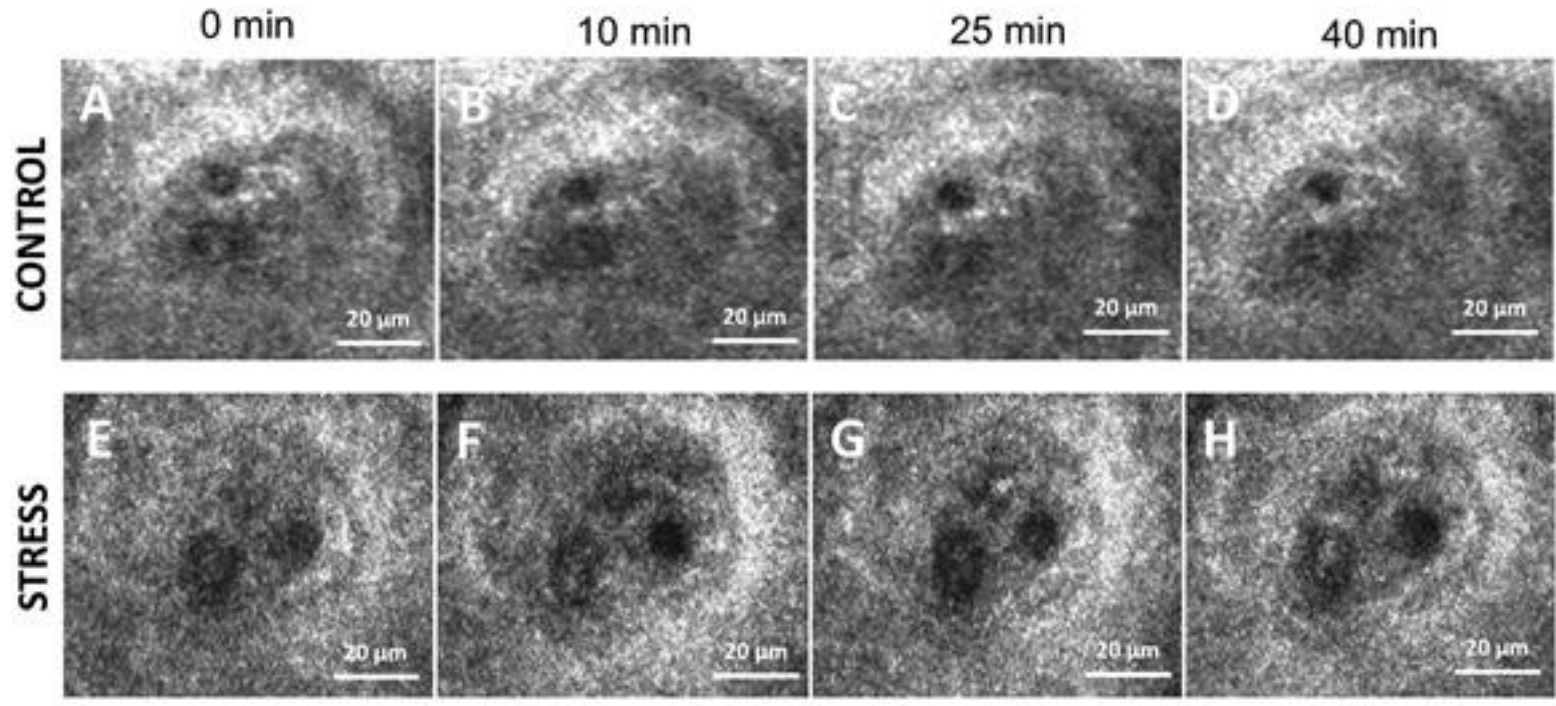

Figure 4.

In vivo reflectance confocal microscopy sequential images focusing on one dermal papillae from the control group (A-D) and one from the stress group (E-F) at 0, 10, 25 and 40 minutes after topical capsaicin was applied on the skin. Capsaicin induces vasodilation of dermal capillaries that becomes visible in both groups at 10 minutes after its application and becomes stronger at 25 and 40 minutes. This vasodilatory effect is more prominent in the stress group, thus supporting the amplifying influence of stress on skin inflammation.

Evaluation of the dermal capillaries via in vivo $\mathrm{RCM}$ at 10, 25 and 40 minutes noted an increase in their surface area, perimeter and maximum diameter in both study groups when capsaicin was applied topically (Figure 2 and Figure 4). These findings translate a capsaicin-induced inflammatory reaction obtained minutes after application and sustained for at least 40 minutes. In addition, significantly higher values were obtained in the stress group at 25 and 40 minutes for all parameters, and at 10 minutes for the maximum diameter variation, when compared with the control group (Figure 3 and Figure 4).

The influence of stress on skin neurogenic inflammation has already been demonstrated using other methods and points to a sympathetic activation that can amplify the vasodilatory effect induced by capsaicin $[10,20]$. Additionally, plasmatic levels of norepinephrine correlate with the inflammatory response caused by capsaicin 
FARMACIA, 2021, Vol. 69, 4

[20] and a finding that endorses our study is that our mental stress induction protocol triggers an important sympathetic activation, demonstrated by an increased skin conductance [10].

Stress can facilitate the activity of dorsal root neurons by modulating the effect of catecholamines on capsaicinsensitive nerve fibres density and activity [19], as well as on TRPV1 desensitization [30, 32] and expression levels $[1,15,16]$. These changes may result in increased release of neuropeptides SP and CGRP from skin nociceptive nerves and mast cell degranulation in glabrous and hairy skin, which further explains the augmenting effect of acute stress on skin inflammation induced by capsaicin [20].

\section{Conclusions}

Acute exposure to psychological stress in human subjects leads to amplification of capsaicin-induced neurogenic inflammation, with significantly larger section area and higher perimeter and maximum diameter of the capillaries in the stress group, compared to controls. This response could be mediated by sympathetic activation, and possibly by an increase of mast-cell degranulation. Further research may be useful to clarify the complex involvement of the nervous system in the local capsaicin-induced inflammatory response.

\section{Acknowledgement}

This research and APC were funded by a grant of the Romanian Ministry of Research and Innovation, CCCDI-UEFISCDI, (project number 61PCCD/2018 PN-III-P1-1.2-PCCDI-2017-0341), within PNCDI-III.

\section{Conflict of interest}

The authors declare no conflict of interest.

\section{References}

1. Aghazadeh A, Feizi MAH, Fanid LM, Ghanbari M, Roshangar L, Effects of Hyperthermia on TRPV1 and TRPV4 Channels Expression and Oxidative Markers in Mouse Brain. Cell Mol Neurobiol., 2020.

2. Agozzino M, Moscarella E, Babino G, Caccavale S, Piccolo V, Argenziano G, The use of in vivo reflectance confocal microscopy for the diagnosis of melanoma. Expert Rev Anticancer Ther, 2019; 19(5): 413-21.

3. Altintas AA, Guggenheim M, Oezcelik A, Gehl B, Aust MC, Altintas MA, Local burn versus local cold induced acute effects on in vivo microcirculation and histomorphology of the human skin. Microsc Res Tech., 2011; 74(10): 963-969.

4. Baron R, Wasner G, Borgstedt R, Hastedt E, Schulte H, Binder A, Kopper F, Rowbotham M, Levine JD, Fields HL, Effect of sympathetic activity on capsaicin-evoked pain, hyperalgesia, and vasodilatation. Neurology, 1999; 52(5): 92332 .
5. Brain SD, Williams TJ, Inflammatory oedema induced by synergism between calcitonin gene-related peptide (CGRP) and mediators of increased vascular permeability. Br J Pharmacol., 1985; 86(4): 855-60.

6. Choi JE, Di Nardo A, Skin neurogenic inflammation. Semin Immunopathol., 2018; 40(3): 249-259.

7. Ciulu-Costinescu F, Podgoreanu P, Delcaru C, Simionescu A, Georgescu EF, Bostan M, Chifiriuc MC, Antimicrobial assay of a capsaicin - $\alpha$-cyclodextrin inclusion complex against planktonic and adherent cells. Farmacia, 2019; 67(3): 496-503.

8. Elokely K, Velisetty P, Delemotte L, Palovcak E, Klein ML, Rohacs T, Carnevale V, Understanding TRPV1 activation by ligands: Insights from the binding modes of capsaicin and resiniferatoxin. Proc Natl Acad Sci USA., 2016; 113(2): E137-E145.

9. González S, Gilaberte-Calzada Y, In vivo reflectance-mode confocal microscopy in clinical dermatology and cosmetology. Int J Cosmet Sci, 2008; 30(1): 1-17.

10. Grigore O, Mihailescu AI, Solomon I, Boda D, Caruntu C, Role of stress in modulation of skin neurogenic inflammation. Exp Ther Med., 2019; 17(2): 997-1003.

11. Holst H, Arendt-Nielsen L, Mosbech H, Serup J, Elberling $J$, Capsaicin-induced neurogenic inflammation in the skin in patients with symptoms induced by odorous chemicals. Skin Res Technol, 2011; 17(1): 82-90.

12. Holzer P, Local effector functions of capsaicinsensitive sensory nerve endings: involvement of tachykinins, calcitonin gene-related peptide and other neuropeptides. Neuroscience, 1988; 24(3): 739-768.

13. Holzer P, Capsaicin: cellular targets, mechanisms of action, and selectivity for thin sensory neurons. Pharmacol Rev., 1991; 43(2): 143-201.

14. Hoogedoorn L, Peppelman M, van de Kerkhof PC, van Erp PE, Gerritsen MJ, The value of in vivo reflectance confocal microscopy in the diagnosis and monitoring of inflammatory and infectious skin diseases: a systematic review. Br J Dermatol, 2015; 172(5): 1222-48.

15. Hsu CC, Chien KH, Yarmishyn AA, Buddhakosai W, Wu WJ, Lin TC, Chiou SH, Chen JT, Peng CH, Hwang DK, Chen SJ, Chang YL, Modulation of osmotic stress-induced TRPV1 expression rescues human iPSC-derived retinal ganglion cells through PKA. Stem Cell Res Ther., 2019; 10(1): 284: 1-14.

16. Kobata K, Iwasawa T, Iwasaki Y, Morita A, Suzuki Y, Kikuzaki H, Nakatani N, Watanabe T, Capsaicinol: Synthesis by Allylic Oxidation and Its Effect on TRPV1-Expressing Cells and Adrenaline Secretion in Rats. Biosci Biotechnol Biochem., 2006; 70(8): 1904-1912.

17. Lambe J, Saidha S, Bermel RA, Optical coherence tomography and multiple sclerosis: Update on clinical application and role in clinical trials. Mult Scler., 2020; 26(6): 624-639.

18. Levine A, Markowitz O, In vivo reflectance confocal microscopy. Cutis, 2017; 99(6): 399-402.

19. Lin Q, Li D, Xu X, Zou X, Fang L, Roles of TRPV1 and neuropeptidergic receptors in dorsal root reflexmediated neurogenic inflammation induced by intradermal injection of capsaicin. Mol Pain, 2007; 3: 30: 1-14. 
20. Lutgendorf S, Logan H, Kirchner HL, Rothrock N, Svengalis S, Iverson K, Lubaroff D, Effects of relaxation and stress on the capsaicin-induced local inflammatory response. Psychosom Med., 2000; 62(4): 524-534.

21. Nishimura Y, Fukuda Y, Okonogi T, Yoshikawa S, Karasuyama H, Osakabe N, Ikegaya Y, Sasaki T, Adachi T, Dual real-time in vivo monitoring system of the brain-gut axis. Biochem Biophys Res Commun, 2020; 524(2): 340-5.

22. Podolsky I, Shtrygol S, The behavioral study of the effects of atristamine on the serotonin, dopamine and norepinephrine neurotransmitter systems in mice. Farmacia, 2019; 67(2): 296-304.

23. Popescu GDA, Scheau C, Badarau IA, Dumitrache MD, Caruntu A, Scheau AE, Costache DO, Costache RS, Constantin C, Neagu M, Caruntu C, The Effects of Capsaicin on Gastrointestinal Cancers. Molecules, 2020; 26(1): 94: 1-17.

24. Scheau C, Mihai LG, Bădărău IA, Caruntu C, Emerging applications of some important natural compounds in the field of oncology. Farmacia, 2020; 68(6): 984-991.

25. Scholzen T, Armstrong CA, Bunnett NW, Luger TA, Olerud JE, Ansel JC, Neuropeptides in the skin: interactions between the neuroendocrine and the skin immune systems. Exp Dermatol., 1998; 7(2-3): 81-96.

26. Shahriari N, Grant-Kels JM, Rabinovitz H, Oliviero $\mathrm{M}$, Scope A, In vivo reflectance confocal microscopy image interpretation for the dermatopathologist. $J$ Cutan Pathol., 2018; 45(3): 187-197.

27. Sinclair SR, Kane SA, Van der Schueren BJ, Xiao A, Willson KJ, Boyle J, de Lepeleire I, Xu Y, Hickey L, Denney WS, Li CC, Palcza J, Vanmolkot FH, Depre M, Van Hecken A, Murphy MG, Ho TW, de Hoon JN, Inhibition of capsaicin-induced increase in dermal blood flow by the oral CGRP receptor antagonist, telcagepant (MK-0974). Br J Clin Pharmacol., 2010; 69(1): 15-22.
28. Ständer S, Luger T, Metze D, Treatment of prurigo nodularis with topical capsaicin. $J$ Am Acad Dermatol, 2001; 44(3): 471-8.

29. Szolcsányi J, Capsaicin and sensory neurones: a historical perspective. Prog Drug Res, 2014; 68: 137.

30. Szolcsányi J, Sándor Z, Petho G, Varga A, Bölcskei K, Almási R, Riedl Z, Hajos G, Czéh G, Direct evidence for activation and desensitization of the capsaicin receptor by $\mathrm{N}$-oleoyldopamine on TRPV1-transfected cell, line in gene deleted mice and in the rat. Neurosci Lett, 2004; 361(1-3): 155-8.

31. Terkelsen AJ, Bach FW, Jensen TS, Experimental forearm immobilization in humans reduces capsaicininduced pain and flare. Brain Res., 2009; 1263: 43-49.

32. Touska F, Marsakova L, Teisinger J, Vlachova V, A "cute" desensitization of TRPV1. Curr Pharm Biotechnol, 2011; 12(1): 122-9.

33. Ulrich M, Lange-Asschenfeldt S, Gonzalez S, Clinical applicability of in vivo reflectance confocal microscopy in dermatology. $G$ Ital Dermatol Venereol, 2012; 147(2): 171-8.

34. Urpe M, Buggiani G, Lotti T, Stress and psychoneuroimmunologic factors in dermatology. Dermatol Clin, 2005; 23(4): 609-17.

35. Van der Schueren BJ, de Hoon JN, Vanmolkot FH, Van Hecken A, Depre M, Kane SA, De Lepeleire I, Sinclair SR, Reproducibility of the capsaicin-induced dermal blood flow response as assessed by laser Doppler perfusion imaging. Br J Clin Pharmacol., 2007; 64(5): 580-590.

36. Xu W, Lv Q, Liu Y, Lai X, Liu F, Tu G, Homology model, docking analysis and molecular dynamics simulation of cannabinoid CB2 receptor. Farmacia, 2020; 68(2): 362-368.

37. Yang F, Zheng J, Understand spiciness: mechanism of TRPV1 channel activation by capsaicin. Protein Cell, 2017; 8(3): 169-77. 